\title{
Long-lasting Memory T Cell Responses following Self-limited Acute Hepatitis B
}

\author{
Amalia Penna, ${ }^{*}$ Marco Artini, ${ }^{\ddagger}$ Albertina Cavalli, ${ }^{*}$ Massimo Levrero,§ Antonio Bertoletti, ${ }^{\star}$ Massimo Pilli, ${ }^{*}$ Francis V. Chisari, \\ Barbara Rehermann," Gianfranco Del Prete, $\|$ Franco Fiaccadori, ${ }^{*}$ and Carlo Ferrari ${ }^{\star}$ \\ * Cattedra Malattie Infettive, Università di Parma, and Divisione Malattie Infettive e Immunopatologia Virale, Azienda Ospedaliera di \\ Parma, 43100, Parma, Italy; ${ }^{\ddagger}$ I Clinica Medica, Università “La Sapienza," and Fondazione A. Cesalpino, Roma, Italy; ${ }^{\S}$ Istituto di \\ Medicina Interna, Università di Cagliari, and Fondazione A. Cesalpino, Roma, Italy; "Clinica Medica III, Università di Firenze, Italy; and \\ "Department of Molecular and Experimental Medicine, The Scripps Research Institute, La Jolla, California
}

\section{Abstract}

The molecular and cellular basis of long-term $\mathrm{T}$ cell memory against viral antigens is still largely undefined. To characterize anti-viral protection by memory $T$ cells against non-cytopathic viruses able to cause acute self-limited and chronic infections, such as the hepatitis B virus (HBV), we studied HLA class II restricted responses against HBV structural antigens in 17 patients with acute hepatitis $B$, during the acute stage of infection and 2.2 to $13 \mathrm{yr}$ after clinical resolution of disease. Results indicate that: (a) significant $T$ cell proliferative responses to $\mathrm{HBV}$ nucleocapsid antigens were detectable in all patients during the acute phase of infection and in 14/17 also 2-13 yr after clinical resolution of disease; b) long-lasting $\mathrm{T}$ cell responses were sustained by $\mathrm{CD} 45 \mathrm{RO}+\mathrm{T}$ cells, predominantly expressing the phenotype of recently activated cells; c) limiting dilution analysis showed that in some patients the frequency of $\mathrm{HBV}$-specific $\mathrm{T}$ cells was comparable to that observed in the acute stage of infection and, usually, higher than in patients with chronic HBV infection; d) the same amino acid sequences were recognized by $T$ cells in the acute and recovery phases of infection; and e) HBV-DNA was detectable by nested-PCR in approximately half of the subjects.

In conclusion, our results show that vigorous anti-viral $\mathrm{T}$ cell responses are detectable in vitro several years after clinical recovery from acute hepatitis B. Detection of minute amounts of virus in some recovered subjects suggests that long-term maintenance of an active anti-viral $T$ cell response could be important not only for protection against reinfection but also for keeping the persisting virus under tight control. (J. Clin. Invest. 1996. 98:1185-1194.) Key words: viremia $•$ cytokines - tetanus $\cdot$ toxoid $\cdot$ HBV nucleocapsid antigens $\cdot \mathrm{HBV}$ envelope antigens

\section{Introduction}

An important property of the immune system is to remember past infections; in this way it can afford a state of protection against the pathogen eventually lasting after resolution of infection (1-3). This property resides into the capacity of mem-

Address correspondence to Carlo Ferrari, M.D., Cattedra Malattie Infettive, Universita Di Parma, Via Gramsci 14, 43100 Parma, Italy. Phone: 39-521-991056; FAX: 39-521-988706.

Received for publication 26 March 1996 and accepted in revised form 12 June 1996.

J. Clin. Invest.

(C) The American Society for Clinical Investigation, Inc.

0021-9738/96/09/1185/10 \$2.00

Volume 98, Number 5, September 1996, 1185-1194 ory $\mathrm{T}$ cells to mount fast and vigorous secondary responses upon re-exposure to the antigen. Accelerated and enhanced memory responses are likely due not only to an intrinsic capacity of memory cells to respond faster and more efficiently than naive cells, but also to an increased frequency of antigen-reactive cells with a less stringent dependence on costimuli for activation $(2,4,5)$. Protection induced by natural infections or vaccines is based on these mechanisms; in most instances, protection can last for years or even a lifetime, but immunity to some pathogens or vaccines can be shorter $(2,5)$. Memory functions at the $\mathrm{B}$ and $\mathrm{T}$ cell level are governed by different rules and may have a different duration $(2,6,7)$. Whether long-term $\mathrm{T}$ cell memory following viral infections is maintained by long-lived $\mathrm{T}$ cell clones $(8-10)$ or whether periodic stimulation with antigen is required to induce division of specific $\mathrm{T}$ cells and to maintain their clonal progeny $(11,12)$ is still debated.

After resolution of acute hepatitis B virus $(\mathrm{HBV})^{1}$ infection, humoral anti-viral responses can last for a lifetime, while little is known about memory $\mathrm{T}$ cell responses against $\mathrm{HBV}$ antigens. Previous studies indicated that traces of virus can persist indefinitely following clinical recovery from hepatitis B $(13,14)$. This suggests that clinical resolution does not necessarily correspond to eradication of HBV and raises the possibility that long-lasting $\mathrm{T}$ cell memory can be maintained by chronic production of minute (and serologically undetectable) amounts of antigen. If HBV persistence in recovered hosts is a common event, even in the face of an immune response leading to disease resolution (15), life-long maintainance of an active anti-viral $\mathrm{T}$ cell response could be important not only for protection against reinfection but also for keeping the virus under a tight and efficient control.

In this study we have followed viremia and HBV-specific $\mathrm{T}$ cell responses several years after resolution of acute hepatitis B. Results show that a memory $\mathrm{T}$ cell response against HBV nucleocapsid antigen can last in most patients for years and even decades although viremia becomes undetectable in some of them.

\section{Methods}

Patients. 17 subjects ( 6 females and 11 males; mean age $41.5 \mathrm{yr}$ ) who recovered from an episode of acute self-limited hepatitis B (mean time from clinical onset, $5.3 \pm 2.2 \mathrm{yr}$ ) were studied (Table I). Diagnosis of acute hepatitis was based on elevated serum glutamic pyruvic transaminase activity, detection of IgM anti-hepatitis B core antigen (anti-

1. Abbreviations used in this paper: $\mathrm{HBV}$, hepatitis $\mathrm{B}$ virus; anti- $\mathrm{HBc}$, anti-hepatitis B core antigen antibodies; $\mathrm{HBsAg}$, hepatitis B surface antigen; $\mathrm{HBeAg}$, hepatitis $\mathrm{B}$ e antigen; $\mathrm{HBcAg}$; hepatitis B core antigen; APC, antigen presenting cells; SI, stimulation index. 
$\mathrm{HBc}$ ) antibodies in the serum and the recent onset of jaundice and other typical symptoms. All patients were negative for antibodies to hepatitis $\mathrm{C}$ virus and to HIV-1, 2 with the exception of patient seven (Table I) who was anti-hepatitis $\mathrm{C}$ virus positive. HBV infection was probably related to sexual exposure at risk in five cases, two patients were partners of chronic HBV carriers, one was infected during acute hepatitis of the partner, one patient had surgery and blood transfusion, two were health care workers, one was a drug abuser. For the remaining five patients no clear cause of infection was established. All patients normalized their transaminase levels within $12 \mathrm{wk}$ and became negative for hepatitis B surface (HBsAg) and "e" ( $\mathrm{HBeAg})$ antigens.

10 healthy subjects (five males and five females; mean age $33.1 \pm 5.8$ ) without evidence of exposure to HBV (i.e., negative for $\mathrm{HBsAg}$ and anti-HBc antibodies) were selected as controls. T cell responses observed in subjects recovered from hepatitis B were also compared with $\mathrm{T}$ cell responses to HBV envelope antigens and tetanus toxoid expressed by 15 anti-HBV and 17 anti-tetanus vaccine recipients ( 4 females and 13 males; mean age 38.2 $\pm 6 \mathrm{yr}$ ) (mean time from the last vaccine dose, $5.7 \pm 2.9 \mathrm{yr}$ and $8.8 \pm 6.3$, respectively).

$H B V$ antigens and synthetic peptides. A recombinant preparation of hepatitis B core antigen ( $\mathrm{HBcAg}$ ) was obtained as described previously (16). Purity was $>95 \%$ as determined by scanning densitometry of Coomassie blue stained SDS-polyacrylamide gel.

A $\mathrm{HBcAg}$ deletion mutant lacking the carboxyl-terminal 39amino acid residues of the core molecule was provided by Biogen (Cambridge, MA) (17). Its purity was $99.8 \%$ and it is herein designated as $\mathrm{HBe} \mathrm{Ag}$.

A purified preparation of $\mathrm{HBV}$ envelope antigens containing the $\mathrm{S}$, preS1, and preS2 region encoded determinants was provided by Sorin Biomedica (Saluggia, Italy) (18). Tetanus toxoid was purchased from Connaught Laboratories Limited (Toronto, Canada). 22 peptides, 10-20-amino acids long, corresponding to the complete sequence of the core and pre-core region encoded polypeptides (subtype ayw), were purchased from Multiple Peptide System (San Diego, CA) and Chiron Mimotopes (Clayton, Victoria, Australia).

Isolation of PBMC and T cell subsets. PBMC were isolated from fresh heparinized blood by Ficoll-Hypaque density gradient centrifugation. T cells and non-T cells were separated by rosetting PBMC with 2-aminoethylisothiuronium bromide (AET; Sigma Chemical
Co., St. Louis, MO) treated sheep erythrocytes (19). The E-rosetteforming $\mathrm{T}$ cells were separated from the non-rosetting (non-T) cells by Ficoll-Hypaque gradient. The $\mathrm{T}$ cell-enriched population contained $>95 \% \mathrm{CD} 3+$ cells, whereas the non-rosetting fraction contained $<3 \%$ of $\mathrm{CD} 3+$ cells.

$\mathrm{CD} 4+$ and CD8 + T cells were purified by immunomagnetic separation using Dynabeads (Dynal A.S., Oslo, Norway), according to manufacturer's instructions.

For negative and positive selection of CD45-RO cells, $\mathrm{T}$ cells were first incubated with a mAb specific for CD45RO $\left(0.1 \mu \mathrm{g} / 10^{6}\right.$ cells; Ancell Corporation, Bayport, MN), washed, and then incubated with goat anti-mouse Ig conjugated magnetic beads (Dynal A.S., Oslo, Norway). After depletion, residual CD45RO cells ranged from 15 to $1.5 \%$ (mean 7\%). Purity of positively selected CD45RO cells was always around $95 \%$. For depletion of activated T cells, a mixture of anti-HLA-DR, CD69 and CD25-IL2 receptor mAbs $\left(0.1 \mu \mathrm{g} / 10^{6}\right.$ cells; Immunotech, Marseille, France) was used. The percentage of residual activated $\mathrm{T}$ cells after depletion ranged between 0 and $1.5 \%$. The purity of $\mathrm{T}$ cell preparations was tested with FITC or phycoeritrin (PE) conjugated mAbs (CD4/CD8, CD3/19, HLA-DR, IL2-rec; Becton Dickinson Monoclonal Center, Inc. Mountain View, CA) (CD45RO; Sigma Chemical Co., St. Louis, MO) (CD69; Immunotech, Marseille, France) on a FACSort flow cytometer (Becton Dickinson Immunocytometry Systems, Inc., Mountain View, CA).

Cell populations were resuspended at $1 \times 10^{6}$ cells $/ \mathrm{ml}$ in RPMI 1640 supplemented with $25 \mathrm{mM}$ Hepes, $2 \mathrm{mM} \mathrm{L}$-glutamine, $50 \mu \mathrm{g} / \mathrm{ml}$ gentamycin, and $8 \%$ human serum (complete medium).

Production of antigen-specific polyclonal T cell lines. PBMC were cultured in 24-well plates $\left(2,5-3 \times 10^{6}\right.$ cells $\left./ 1,5 \mathrm{ml}\right)$ in complete medium, in the presence of $\mathrm{HBeAg}$ or $\mathrm{HBcAg}(0.5 \mu \mathrm{g} / \mathrm{ml})$. After $5 \mathrm{~d}$, activated $\mathrm{T}$ cells were expanded by adding recombinant IL-2 $(30 \mathrm{U} / \mathrm{ml}$; Cetus Corporation, Emeryville, CA). On day 14, lines were tested for antigen specificity and fine specificity with synthetic peptides and were restimulated with antigen in the presence of irradiated (4,000 rads) autologous PBMC $\left(5 \times 10^{5} / \mathrm{ml}\right)$ in medium supplemented with IL-2. T cell lines were then restimulated every $10-14 \mathrm{~d}$ and provided with IL-2 to maintain the cell concentration between $3 \times 10^{5}$ and $1 \times 10^{6}(20)$.

Proliferation assays. Unfractionated PBMC $\left(0.2 \times 10^{6} /\right.$ well $)$ were incubated for $7 \mathrm{~d}$ at $37^{\circ} \mathrm{C}$ in the presence of $\mathrm{HBV}$ nucleocapsid $(0.5$

Table I. Epidemiologic, Virologic, and Immunologic Features of the Patients Studied

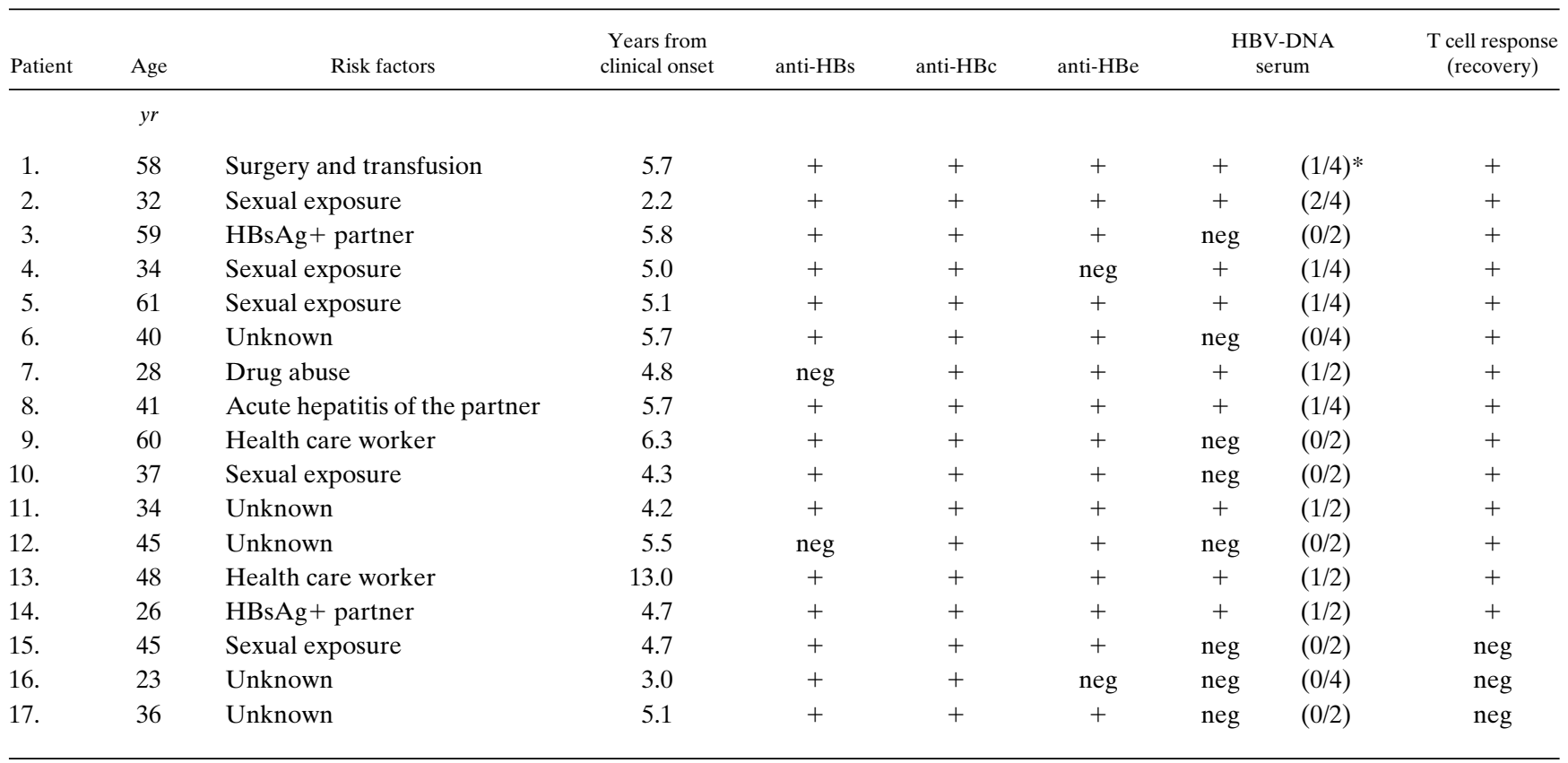

*In parentheses is the number of positive PCR assays over the total number of determinations. 
$\mu \mathrm{g} / \mathrm{ml})$ or envelope $(1 \mu \mathrm{g} / \mathrm{ml})$ antigens, synthetic peptides $(2.5 \mu \mathrm{g} / \mathrm{ml})$ or tetanus toxoid $(0.5 \mu \mathrm{g} / \mathrm{ml})$. In selected experiments, $0.1 \times 10^{6}$ unfractionated $\mathrm{T}$ cells or $\mathrm{T}$ cell subsets were cultured with autologous irradiated PBMC $\left(0.1 \times 10^{6}\right)$ or non-T cells $\left(2 \times 10^{4}\right)$ as antigen presenting cells (APC) in the presence or absence of antigens. For the study of polyclonal $\mathrm{T}$ cell lines, $\mathrm{T}$ cells were washed extensively to remove IL- 2 and cultured $\left(3 \times 10^{4} /\right.$ well $)$ for $3 \mathrm{~d}$ with autologous irradiated PBMC as APC $\left(0.1 \times 10^{6} /\right.$ well $)$ in the presence or absence of antigens or peptides. All proliferation assays were performed in triplicate in 96-well plates and $\left[{ }^{3} \mathrm{H}\right]$ thymidine $\left({ }^{3} \mathrm{H}-\mathrm{TdR} ; 0.5 \mu \mathrm{Ci} /\right.$ well; specific activity, $2.0 \mathrm{Ci} / \mathrm{mmol} / \mathrm{L}$; Amersham International, Buckinghamshire, UK) was added $6 \mathrm{~h}$ before harvesting. Results are expressed as stimulation index (SI) which represents the ratio between the mean cpm obtained in the presence and absence of antigen. SI values above four were regarded as positive (at least two standard deviations above the mean of all SI values obtained with each individual $\mathrm{HBV}$ protein or peptide in normal controls).

HLA-restriction of antigen recognition. Monoclonal antibodies recognizing monomorphic determinants of HLA DR (D1-12; IgG2a), DQ1 (BT3/4; IgG1), DQ2 (XIII358/4; IgG2a), DQ3 (XIV466; IgG2b), DP (B7/21; IgG2a) and a mAb specific for HLA A,B,C, antigens (W6/32; IgG2a) were a gift from Dr. R.S. Accolla (University of Genova, Genova, Italy) (20). Anti-HLA class II mAbs were used at a final dilution of ascitic fluid 1:500; purified W6/32 was used at $1 \mu \mathrm{g} /$ $\mathrm{ml}$. Autologous irradiated APC were incubated first with $\mathrm{mAbs}$ for $1 \mathrm{~h}$ at $37^{\circ} \mathrm{C}$, then with synthetic peptides $\left(0.5 \mu \mathrm{g} / \mathrm{ml}, 1 \mathrm{~h}, 37^{\circ} \mathrm{C}\right)$ or with HBV antigens $\left(0.5 \mu \mathrm{g} / \mathrm{ml}, 4-6 \mathrm{~h}, 37^{\circ} \mathrm{C}\right)$ and finally washed before addition to responder $\mathrm{T}$ cell lines.

Limiting dilution analysis. HBV nucleocapsid-specific T cell frequency was determined by liming dilution analysis. Varying numbers of purified T cells $\left(1 \times 10^{5}, 6 \times 10^{4}, 3 \times 10^{4}, 1 \times 10^{4}, 3 \times 10^{3}, 1 \times 10^{3}\right.$, $\left.3 \times 10^{2}, 1 \times 10^{2}\right)$ were cocultured in individual wells with a constant number of irradiated autologous non-T cells $\left(2 \times 10^{4}\right)$ in the presence or absence of $0.5 \mu \mathrm{g} / \mathrm{ml} \mathrm{HBeAg}$. 32 replicate wells were seeded for each concentration of responder $\mathrm{T}$ cells. ${ }^{3} \mathrm{H}-\mathrm{TdR}$ incorporation was measured after $7 \mathrm{~d}$. Individual cultures stimulated with antigen, showing ${ }^{3} \mathrm{H}-\mathrm{TdR}$ incorporation higher than the arithmetic mean plus three standard deviations of that shown by cultures incubated in the absence of antigen were scored as positive, and the fraction of nonresponder cultures was calculated for each concentration of seeded $\mathrm{T}$ cells. Poisson analysis was applied for the calculation of $\mathrm{T}$ cell frequency (21) using the ELIDA computer program (22).

Lymphokine production and quantitation. $\mathrm{T}$ cells from antigen specific lines were extensively washed and incubated at $1 \times 10^{6} / \mathrm{ml}$ with an equal number of autologous irradiated APC in the presence of antigen or peptides. After $40-48 \mathrm{~h}$, supernatants were collected and stored in aliquots at $-70^{\circ} \mathrm{C}$ until used. IFN- $\gamma$ and IL-4 were quantitated by commercial ELISA assays (BioSource International, Camarillo, CA and Quantikine R \& D Systems, Minneapolis, MN, respectively), as previously described (23). For the measurement of IL5, the murine LyH7.B13 cell line was used as a source of indicator cells (23). Values of cytokines 5 SD over those of control supernatants derived from irradiated APC alone were regarded as positive.

$D N A$ preparation from serum. For the amplification of circulating HBV-DNA genomes, $100 \mu \mathrm{l}$ of serum were incubated at $42^{\circ} \mathrm{C}$ for $3 \mathrm{~h}$ with proteinase $K(50 \mu \mathrm{g} /$ tube $)$ in $200 \mu \mathrm{l}$ lysis buffer $(10 \mathrm{mM}$ TrisHCI, pH 8.0, $10 \mathrm{mM} \mathrm{NaCl}, 10 \mathrm{mM}$ EDTA, pH 8.0, 0.5\% SDS) and DNA was extracted by the phenol chloroform method, precipitated with sodium acetate-ethanol, washed with $70 \%$ ethanol, and dissolved in $20 \mu \mathrm{T}$ TE buffer.

$D N A$ extraction from $P B M C$. PBMC were washed three times, and the final cell wash was saved as a control for contamination of cells with blood derived HBV-DNA. After digesting $10 \times 10^{6} \mathrm{PBMC}$ with proteinase $\mathrm{K}$ in one $\mathrm{ml}$ lysis buffer $(10 \mathrm{mM}$ Tris, $\mathrm{pH}$ 9.0, $10 \mathrm{mM}$ EDTA, $10 \mathrm{mM} \mathrm{NaCl}, 0.5 \%$ SDS) at $37^{\circ} \mathrm{C}$ overnight, DNA was extracted by the phenol-chloroform method, precipitated with sodium acetate-ethanol and dissolved in $200 \mu \mathrm{l} \mathrm{TE}$ buffer. Approximately $1 \mu \mathrm{g}$ of DNA derived from each preparation was used for PCR amplification.
PCR protocol. $10 \mu \mathrm{l}$ of serum DNA sample and $1 \mu \mathrm{g}$ of PBMC genomic DNA were amplified in a reaction buffer containing $10 \mathrm{mM}$ Tris-HCI, $\mathrm{pH} 8.3,50 \mathrm{mM} \mathrm{KCI}, 1.5 \mathrm{mM} \mathrm{MgCI}_{2}$ in a programmable thermal cycler. A nested PCR was carried out using primers derived from the core region of the HBV genome: for the first round of amplification 40 cycles were performed at $94^{\circ} \mathrm{C}$ for $45 \mathrm{~s}, 55^{\circ} \mathrm{C}$ for $45 \mathrm{~s}$, and $72^{\circ} \mathrm{C}$ for $45 \mathrm{~s}$ with the external antisense primer core $4 \mathrm{~B} 5^{\prime} \mathrm{GTA}$ ACA TTG AGA TTC CCG A3' and the external sense primer core 0 5' CTG GGA GGA GTT GGG GGA3'. For the second round the same conditions were adopted using primer sense core $15^{\prime} \mathrm{ACT}$ AGG AGC CTG TAG GCA TAA ATT GGT CT3' and primer anti-

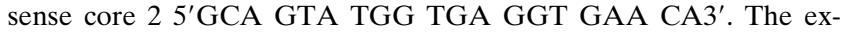
pected size of the product from the second amplification was 289-bp long. PCR products were visualized by ethidium bromide staining on $2 \%$ agarose gels. Our nested PCR method allowed to detect consistently between 10 and 100 copies of HBV-DNA per sample, as assayed using serial dilutions of the $\mathrm{pFC} 80$ plasmid, containing four copies of HBV-DNA cloned into a pBR322 vector (sensitivity limit $5 \mathrm{ng} \times$ $\left.10^{-8}\right)$.

\section{Results}

PBMC responses to $H B V$ antigens and tetanus toxoid. The proliferative $\mathrm{T}$ cell response to $\mathrm{HBV}$ nucleocapsid antigens and peptides observed during the acute phase of HBV infection in a group of 17 patients was compared to the response expressed by the same individuals several years (mean 5.3 $\pm 2.2 \mathrm{yr}$; range 2.2-13 yr; Table I) after resolution of hepatitis (recovery phase). In the acute phase of disease all tested patients (patient 13 was not tested in the acute phase) showed significant $\mathrm{T}$ cell proliferation to HBV nucleocapsid proteins and 14 out of 17 $(82 \%)$ were still able to express significant responses several years later. 11 patients were tested more than once a few months apart during the recovery phase and 4 of them switched their $\mathrm{T}$ cell response from negative to positive, suggesting that the frequency of circulating antigen-specific $T$ cells can fluctuate over time. For example, patient 1 was tested five times and his $\mathrm{T}$ cell response to the HBV nucleoprotein was negative in 2 instances; patients 6 and 8 were tested four times and in both the response was positive in three separate experiments; patient five was tested twice and showed one positive and one negative response. Therefore, persistence of HBVspecific memory $\mathrm{T}$ cells in the three non-responsive patients (patients 15, 16, and 17; Table I) cannot be totally excluded because their responsiveness to HBV antigens was tested only once.

To assess whether maintenance of $\mathrm{T}$ cell responses in the recovery phase was associated with viral persistence, HBVDNA was tested by nested PCR in serum and PBMC. At least two PCR assays were performed in each patient. In seven subjects two different DNA extractions of two different time points were analyzed, for a total of four PCR determinations. HBV-DNA was detected at least once in the serum of 9 out of the 17 subjects (Table I), while PBMC were PCR negative, indicating either absence of HBV-DNA or the presence of less than 10 copies of HBV-DNA per haploid genome. All these results suggest a very low level of HBV viremia in these patients, near the sensitivity limit of our method.

The behavior of the T cell response to HBV envelope antigens was apparently similar to that against HBV nucleocapsid antigens because the percentage of significant proliferative responses after recovery (20\%) was equivalent to that detected in the acute phase of hepatitis $(24 \%)$. Whether this finding is 
biologically relevant remains however unclear because the proliferative responses to HBV envelope antigens were only slightly above background, irrespective of the stage of infection (Table II and data not shown). For this reason, further phenotypic and functional characterization was focused on "memory" responses to HBV nucleocapsid proteins.

T cell responses to HBV antigens after recovery were compared to $\mathrm{T}$ cell responses against tetanus toxoid and HBV envelope antigens in 15 anti-HBV and 17 anti-tetanus vaccine recipients immunized an average of 5.7 and $8.8 \mathrm{yr}$ earlier, respectively. Significant levels of $\mathrm{T}$ cell responses were detectable in $47 \%$ of anti-HBV and $76 \%$ of anti-tetanus toxoid vaccine recipients (Table II). Responses to HBV envelope antigen by vaccine recipients were significantly stronger $(P<0.03$ by Student's $t$ test) than those detected in naturally immunized subjects recovered from hepatitis.

Hierarchy of $H B V$ nucleocapsid epitopes recognized by $T$ cells during acute infection and after clinical recovery. In general, peptides able to recall significant responses in the acute phase of infection were still recognized by PBMC isolated several years later (Fig. 1). In addition, an amplification of peripheral blood $\mathrm{T}$ cell responses was observed during the recovery phase of hepatitis. In fact, when responses to the peptides used at both time points were compared, a statistically significant difference was observed ( $P=0.0001$ by Student's $t$-test for paired values) between the number of peptides able to induce $T$ cell proliferation in the acute versus the recovery phase of disease.

To compare the hierarchy of immunodominance of the different epitopes identified by direct PBMC stimulation with synthetic peptides at different stages of infection, polyclonal $\mathrm{T}$ cell lines were produced from PBMC derived from acute infection and from the recovery phase by stimulation with $\mathrm{HBV}$ nucleocapsid antigen in the presence of IL2. The capacity of the polyclonal $\mathrm{T}$ cell lines to recognize the same peptides that were stimulatory for parental PBMC was tested. As illustrated in Fig. 2, T cell lines derived from the same patient at different time points showed similar patterns of fine specificity, indicating that the hierarchy of nucleocapsid epitopes generated by the intracellular processing of the whole protein was maintained unchanged throughout the years.

$H L A$ restriction of responder $T$ cells. HBV nucleocapsid-specific $\mathrm{T}$ cell responses were in general HLA class II restricted, because in most experiments proliferation of $\mathrm{T}$ cell lines induced by HBV nucleoprotein stimulation was inhibited by anti-HLA class II, but not anti-class I mAbs (Fig. 3). Proliferative responses were generally inhibited by more than one anti-HLA class II mAb (Fig. 3, top) as a result of the multispecificity of the T cell lines which were able to recognize multiple epitopes in association with different HLA molecules. For example, the region spanning residues 1-27 contains at least 2 distinct HLA class II restricted epitopes that can be recognized in association with DR, DQ and DP molecules, as shown by anti-HLA antibody inhibition of the peptide-induced proliferative response of polyclonal $\mathrm{T}$ cell lines produced by stimulation with $\mathrm{HBV}$ nucleocapsid antigens (Fig. 3, bottom). Interestingly, the nucleocapsid sequence 18-27 that was previously shown to be an important HLA-A0201restricted CTL epitope, can also be recognized in association with HLA DP molecules (subject 6; Fig. 3, bottom).

Table II. Proliferative T Cell Response to HBV Antigens and to Tetanus Toxoid in Subjects Recovered from Acute Hepatitis B and in Anti-HBV and Anti-TT Vaccine Recipients

\begin{tabular}{|c|c|c|c|c|c|c|c|c|}
\hline \multicolumn{4}{|c|}{ Natural infection } & \multicolumn{5}{|c|}{ Vaccination } \\
\hline \multirow{2}{*}{$\begin{array}{l}\text { Subject } \\
1 .\end{array}$} & \multicolumn{2}{|l|}{ HBV envelope } & \multirow{2}{*}{$\frac{\mathrm{HBV} \text { nucleoprotein }}{17.3^{\wedge}}$} & \multirow{2}{*}{$\begin{aligned} \text { Subject } \\
1 .\end{aligned}$} & \multicolumn{2}{|c|}{ HBV envelope } & \multicolumn{2}{|c|}{ Tetanus toxoid } \\
\hline & - & $(5.7)^{*}$ & & & - & $(6.0)^{* *}$ & 6.6 & $(6.0)^{* *}$ \\
\hline 2. & 5.7 & $(2.2)$ & 15.5 & 2. & 25.0 & (3.0) & 30.5 & $(18.0)$ \\
\hline 3. & - & (5.8) & 16.6 & 3. & - & $(7.0)$ & 7.6 & $(7.0)$ \\
\hline 4. & - & (5.0) & 37.0 & 4. & 9.6 & (8.0) & 11.6 & $(15.0)$ \\
\hline 5. & - & (5.1) & 25.7 & 5. & - & $(5.0)$ & - & $(6.0)$ \\
\hline 6. & - & (5.7) & 88.0 & 6. & 7.4 & $(11.0)$ & 12.4 & (1.0) \\
\hline 7. & - & (4.8) & 11.9 & 7. & - & $(9.0)$ & - & $(18.0)$ \\
\hline 8. & 4.3 & (5.7) & 22.6 & 8. & 14.0 & (3.0) & 6.9 & $(15.0)$ \\
\hline 9. & NT & (6.3) & 13.0 & 9. & NT & & 13.9 & $(3.0)$ \\
\hline 10. & 6.5 & (4.3) & 6.7 & 10. & - & $(2.0)$ & 4.5 & (3.0) \\
\hline 11. & - & $(4.2)$ & 8.0 & 11. & - & $(5.0)$ & 6.7 & (1.0) \\
\hline 12. & NT & (5.5) & 18.3 & 12. & - & (1.0) & - & $(6.0)$ \\
\hline 13. & - & (13.0) & 9.3 & 13. & - & $(8.0)$ & 15.4 & $(14.0)$ \\
\hline 14. & - & (4.7) & 40.0 & 14. & 20.7 & $(9.0)$ & 22.4 & $(5.0)$ \\
\hline 15. & NT & (4.7) & - & 15. & 14.1 & $(5.0)$ & - & $(20.0)$ \\
\hline 16. & - & $(3.0)$ & - & 16. & NT & & 20.4 & $(6.0)$ \\
\hline 17. & NT & (5.1) & - & 17. & 5.6 & $(4.0)$ & 26.6 & $(6.0)$ \\
\hline \multirow[t]{2}{*}{ Responders } & $3 / 15$ & & $14 / 17$ & Responders & $7 / 15$ & & $13 / 17$ & \\
\hline & $20 \%$ & & $82 \%$ & & $47 \%$ & & $76 \%$ & \\
\hline
\end{tabular}

\footnotetext{
* Years from clinical onset

$\wedge$ Stimulation index

** Years from immunization

- Negative result

NT Not tested
} 

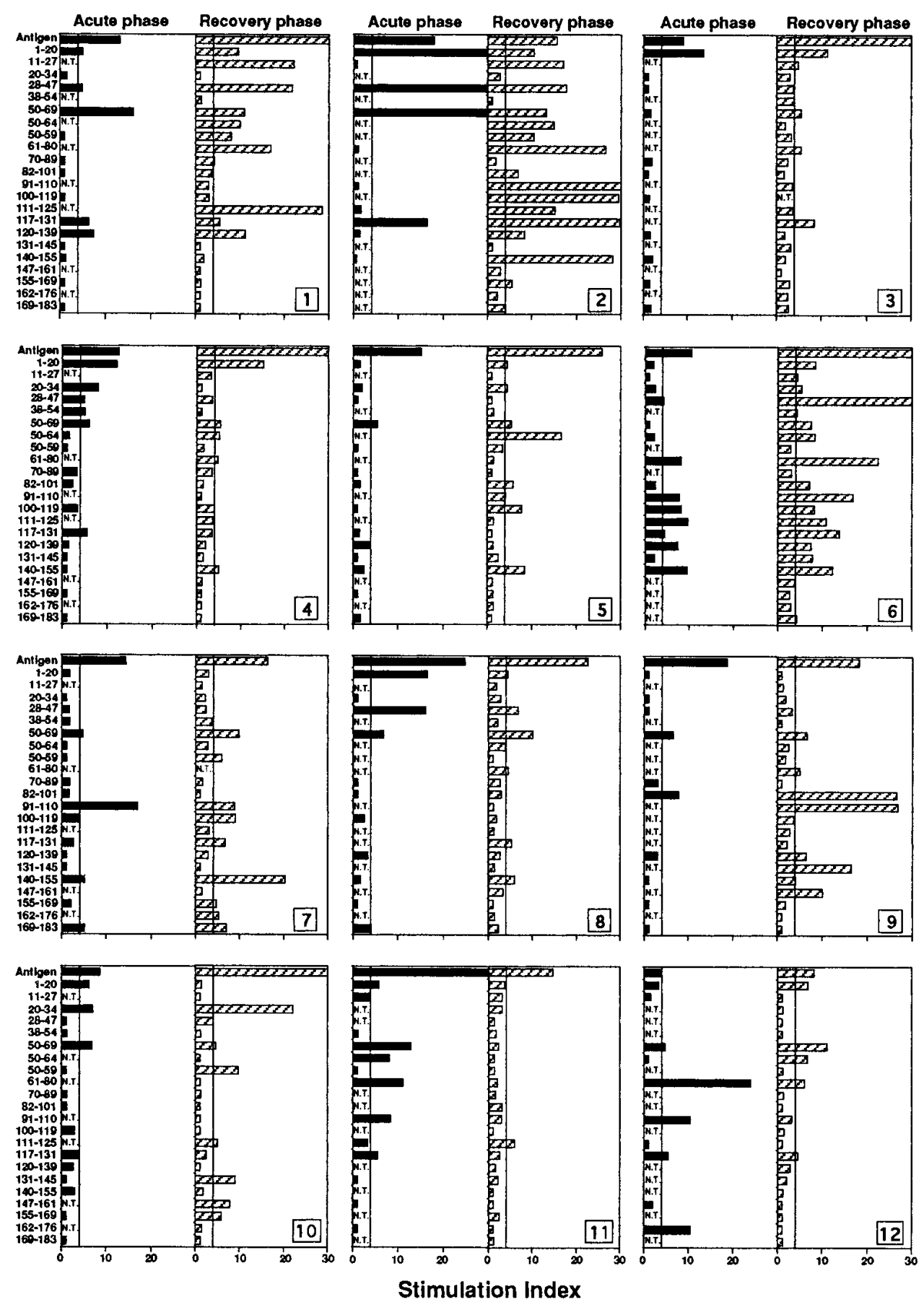

Figure 1. PBMC proliferative response to HBV nucleocapsid antigen and HBV core synthetic peptides. The black bars in the left side of each panel represent the response during the acute phase of hepatitis; the hatched bars on the right side, the response measured at the times after clinical onset reported in Table I. Only freshly isolated PBMC were used for these experiments. Synthetic peptides are indicated by the amino acid position from the $\mathrm{NH}_{2}$-terminus of the HBV core antigen. Patients are illustrated in the same sequence as in Table I. Patient 13 is not illustrated because he was not tested during the acute phase of infection; patient 14 was tested only with HBV proteins. SI values $>4$ (indicated by the vertical line) are considered significant.
Inhibition by anti-HLA class I antibodies was sporadic and partial (Fig. 3, top) suggesting the presence of a minor population of HLA class I restricted T-cells proliferating in response to exogenous antigen.

Phenotypic features of $H B V$ nucleocapsid-specific memory $T$ cells. In line with HLA restriction results, synthetic peptides were recognized by $\mathrm{CD} 4+$ and $\mathrm{CD} 8+\mathrm{T}$ cells purified from PBMC, but most of them preferentially induced proliferation of CD4+T cells (Fig. 4). Also a CD8 proliferative response was stimulated by recombinant $\mathrm{HBV}$ nucleocapsid antigens (subjects 4 and 6; Fig. 4). Since the absolute number of contaminant CD4 cells within the purified CD8 cells seeded in each well was 0.8 for patient four and 0.05 for patient six (calculation based on the frequency of specific $\mathrm{T}$ cells that was 1:3,600 in patient four and 1:2,000 in patient six; see below), it is unlikely that the proliferative response by the purified $\mathrm{CD} 8+$ cells was due to residual CD4+ T cells.

Depletion experiments were carried out to assess whether $\mathrm{T}$ cells responsive to $\mathrm{HBV}$ nucleocapsid belonged to the $\mathrm{CD} 45-\mathrm{RO}+$ subset and whether proliferative reponses were sustained by activated or resting T cells.

In all patients tested, $\mathrm{T}$ cell responses to HBV nucleocapsid were sustained by $\mathrm{CD} 45-\mathrm{RO}+$ cells since proliferation was abrogated by depletion of CD45-RO+ cells but it was detectable 

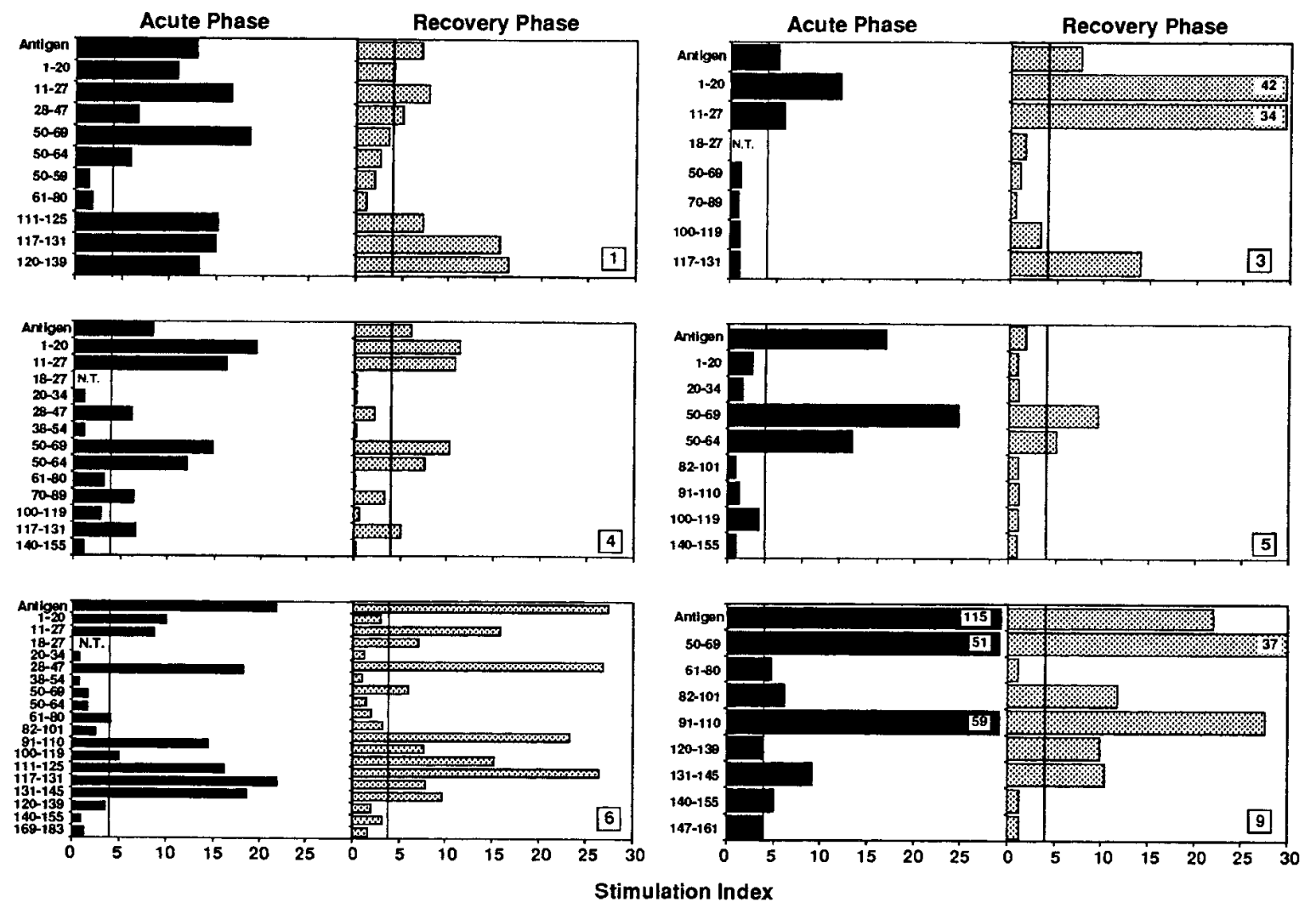

Figure 2. Fine specificity of HBV nucleocapsid-specific polyclonal T cell lines. T cell lines were produced from each patient by HBV nucleocapsid antigen stimulation of PBMC derived from the acute (black bars) or the recovery phase (gray bars) of infection at the same time points illustrated in Fig. 1. Numbers inside bars represent SI values $>$ 30. Patients' numbers correspond to those listed in Table I.

in $\mathrm{CD} 45-\mathrm{RO}+$-enriched populations (Fig. 5). Identical results were obtained in control experiments carried out in two recovered subjects who were sensitized to tetanus toxoid (Fig. 5).

The role of $\mathrm{T}$ cells expressing surface activation markers (HLA-DR, CD69, and CD25) in the recognition of nucleocapsid antigens was then investigated. In four out of eight experiments (S3, S4, and S8; Fig. 6 A), depletion of activated T cells abrogated the HBV nucleocapsid specific $\mathrm{T}$ cell response and in one case (S9; Fig. $6 A$ ) a partial decrease was observed. Only in two experiments performed in vaccinated subjects a partial inhibition of HBV envelope (C2; Fig. $6 B$ ) or tetanus toxoid (C1; Fig. $6 B$ ) recognition was observed upon depletion of activated T cells.

Cytokine secretion by HBV nucleocapsid-specific T cells during acute infection and following clinical recovery. A total of 34 HBV nucleocapsid-specific polyclonal $\mathrm{T}$ cell lines produced by antigen stimulation of PBMC from the acute (15 T cell lines from 9 patients) or recovery (19 $\mathrm{T}$ cell lines from 6 patients) phase were tested for their production of IFN- $\gamma$, IL4, and IL5 upon antigen or peptide stimulation. $67 \%$ of the $\mathrm{T}$ cell lines generated during the acute phase showed a Th1 and 33\% a Th0 cytokine profile. In contrast, $\mathrm{T}$ cell lines generated during the recovery phase showed an opposite profile with a prevalence of Th0- (74\%) over Th1-type lines (21\%) (Fig. 7).

Frequency of peripheral blood HBV nucleocapsid-specific $T$ cells. The frequency of circulating HBV nucleocapsid-specific T lymphocytes was evaluated in 10 of the 14 recovered subjects whose $\mathrm{T}$ cells were responsive to HBV nucleoprotein (Fig. $8 A$ ). Since the frequency of HBV nucleocapsid-specific $\mathrm{T}$ cells during the acute phase of infection was not available in this group of subjects, results were compared with those observed in a group of randomly selected patients with chronic HBV infection (Fig. 8 $A$ ) and in other patients with self-limited hepatitis B during the acute phase of disease (Fig. $8 \mathrm{~B}$ ). While most chronic patients had $\mathrm{T}$ cell frequencies close to the sensitivity threshold of the method (mean $\mathrm{T}$ cell frequency, 1:329,000), as a reflection of the fact that most of them are hyporesponsive at the $\mathrm{T}$ cell level to HBV nucleocapsid antigens (15), most recovered subjects showed $\mathrm{T}$ cell frequencies (mean $\mathrm{T}$ cell frequency, 1:35,757) similar to those detectable during the acute phase of infection, as illustrated in figure $8 B$ by two representative patients followed sequentially during the course of acute hepatitis B.

No correlation was found in recovered subjects between frequency of HBV circulating nucleocapsid-specific $\mathrm{T}$ cells and detection of $\mathrm{HBV}$ viremia or time elapsed from clinical recovery.

\section{Discussion}

HBV can cause either acute self-limited or chronic infections with possible integration of viral DNA into the host's genome. Chronic persistence of HBV is generally associated with weak HLA class I and class II restricted T cell responses to structural and non structural HBV antigens (14, 24-27). These responses are frequently undetectable in the peripheral blood, despite antigen persistence. The molecular basis of this hyporesponsiveness is still largely undefined. In contrast, resolution of acute hepatitis is associated with the production of neutralizing anti-envelope antibodies and the development of anti-viral T cell responses $(14,24-27)$. 

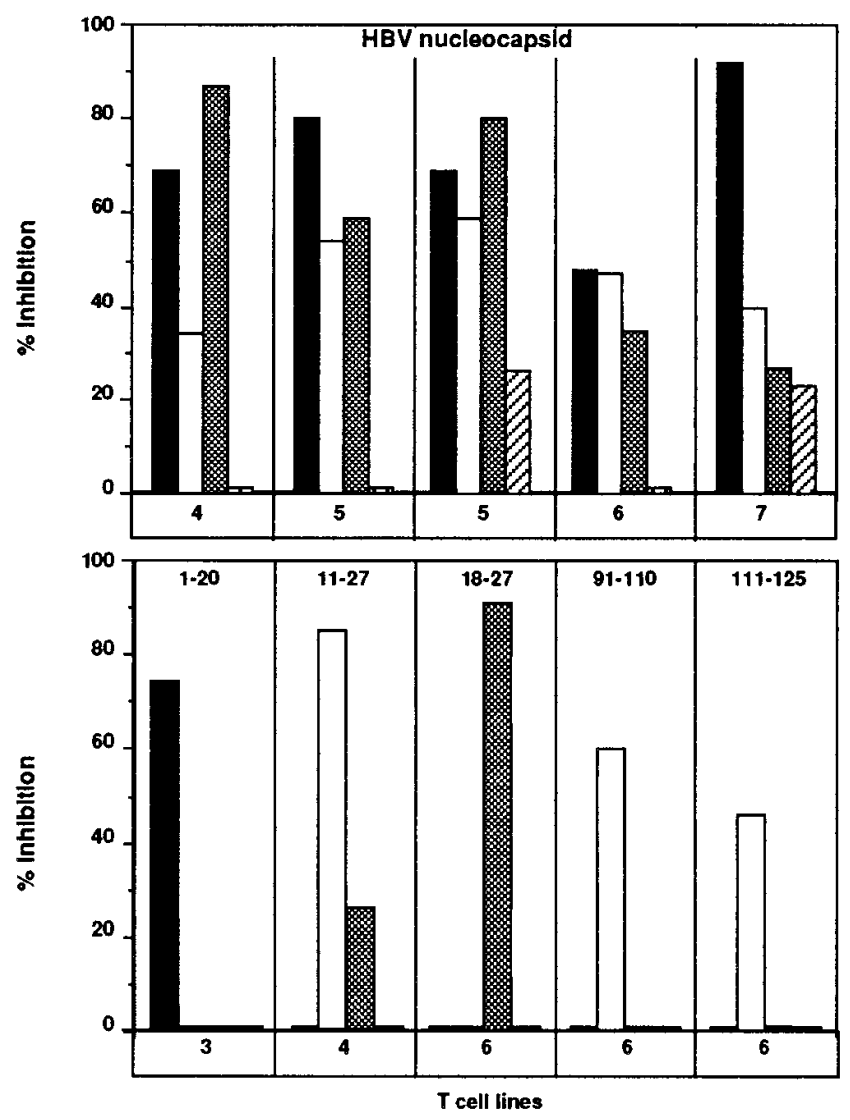

Figure 3. HLA restriction of antigen or peptide recognition by HBV nucleocapsid-specific polyclonal T cell lines. All lines were produced by PBMC stimulation with HBV nucleoprotein and tested with antigen or peptides as indicated at the top of each panel. Results are expressed as percent inhibition of the antigen- or peptide-induced proliferative response caused by APC preincubation with anti-class II (ם, anti-DR; $\square$, anti-DQ; 曲, anti-DP) or -class I $\square$ monoclonal antibodies (for details see Methods). Numbers at the bottom of each panel indicate the patient from whom $\mathrm{T}$ cell lines were obtained.

The concept that disease resolution corresponds to eradication of infection has recently been challenged by the observation that trace amounts of virus detectable by PCR can persist in serum and PBMC of at least some patients long after clinical recovery $(13,14)$. This is consistent with the hypothesis that integration or infection of immunologically privileged sites may allow the virus to escape complete elimination even in the presence of an immune response able to terminate disease. Extensive but incomplete viral clearance may save a source of antigen able to boost periodically specific responses, thus maintaining the pool of anti-viral T cells, perhaps for the lifetime.

Apparently at variance with this prediction, CD4-mediated responses to $\mathrm{HBV}$ nucleocapsid antigens (the most powerful immunogens for HLA class II-restricted $\mathrm{T}$ cells in the acute phase of infection) have been observed to decrease and wane in some acutely infected patients concurrent with, or shortly after, recovery $(20,24)$. This may reflect removal of effector cells that have become redundant and superfluous at the end of a successful immune response $(3,28)$.

To investigate the behavior of $\mathrm{HBV}$-specific $\mathrm{T}$ cell responses long after resolution of acute hepatitis $\mathrm{B}$ and possible correlations with persistence of trace amounts of virus as a po-
S.I.
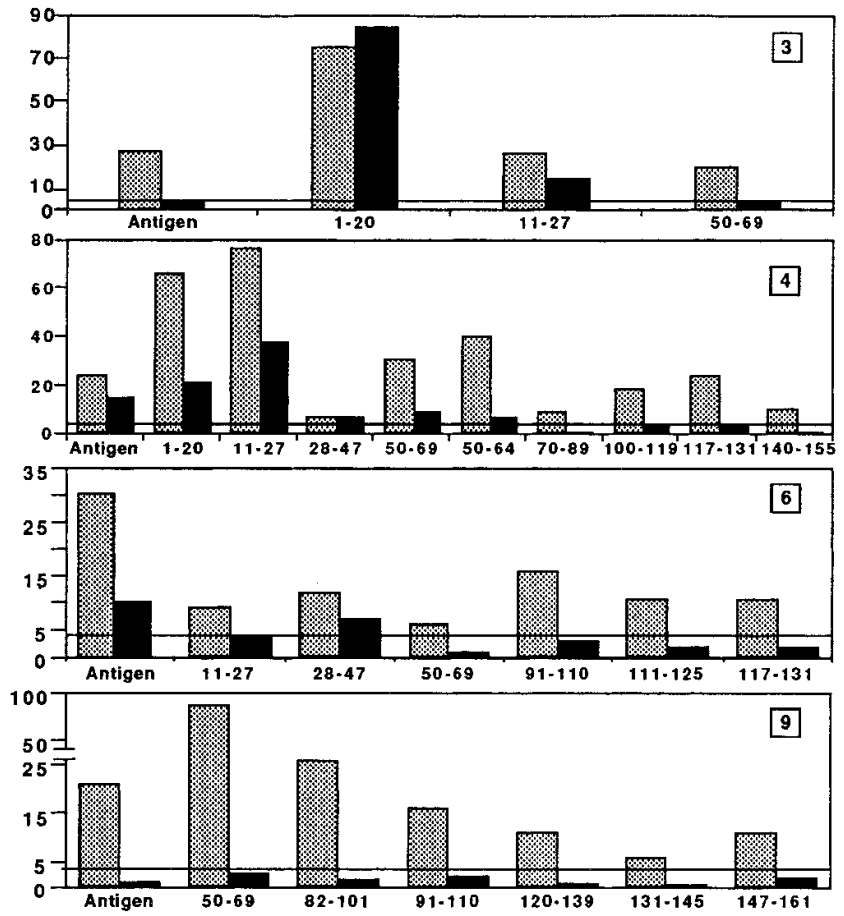

Figure 4. Proliferative response to HBV nucleocapsid antigen and core peptides of CD4+ and CD8 $+\mathrm{T}$ cell subsets. T cell subsets were purified from PBMC of the recovery phase (times after clinical onset reported in Table I). Only significant responses are illustrated.

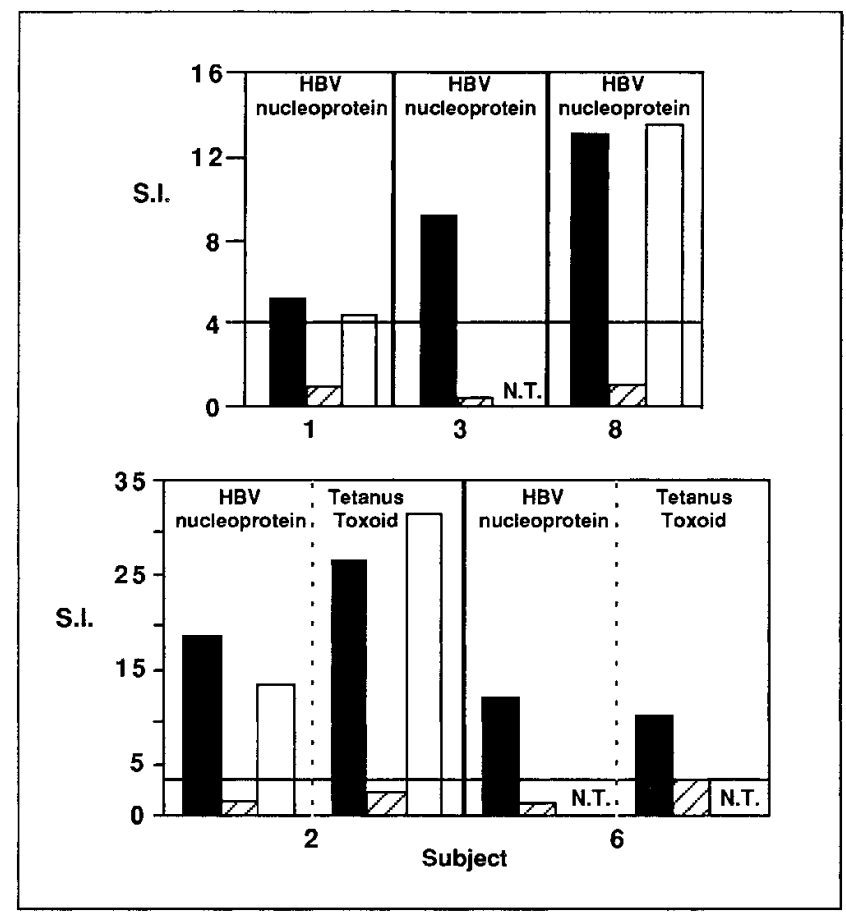

Figure 5. Memory T cell responses to HBV nucleocapsid antigen are sustained by CD45-R0 + cells. Proliferative responses to HBV nucleocapsid antigen and tetanus toxoid of unfractionated ( $\square$ ), CD45-RO depleted $(\varangle)$ and CD45-RO enriched $(\square)$ T cells are illustrated. Subjects' numeration corresponds to that used in Table I. Responses were studied at the times after clinical onset reported in Table I. 


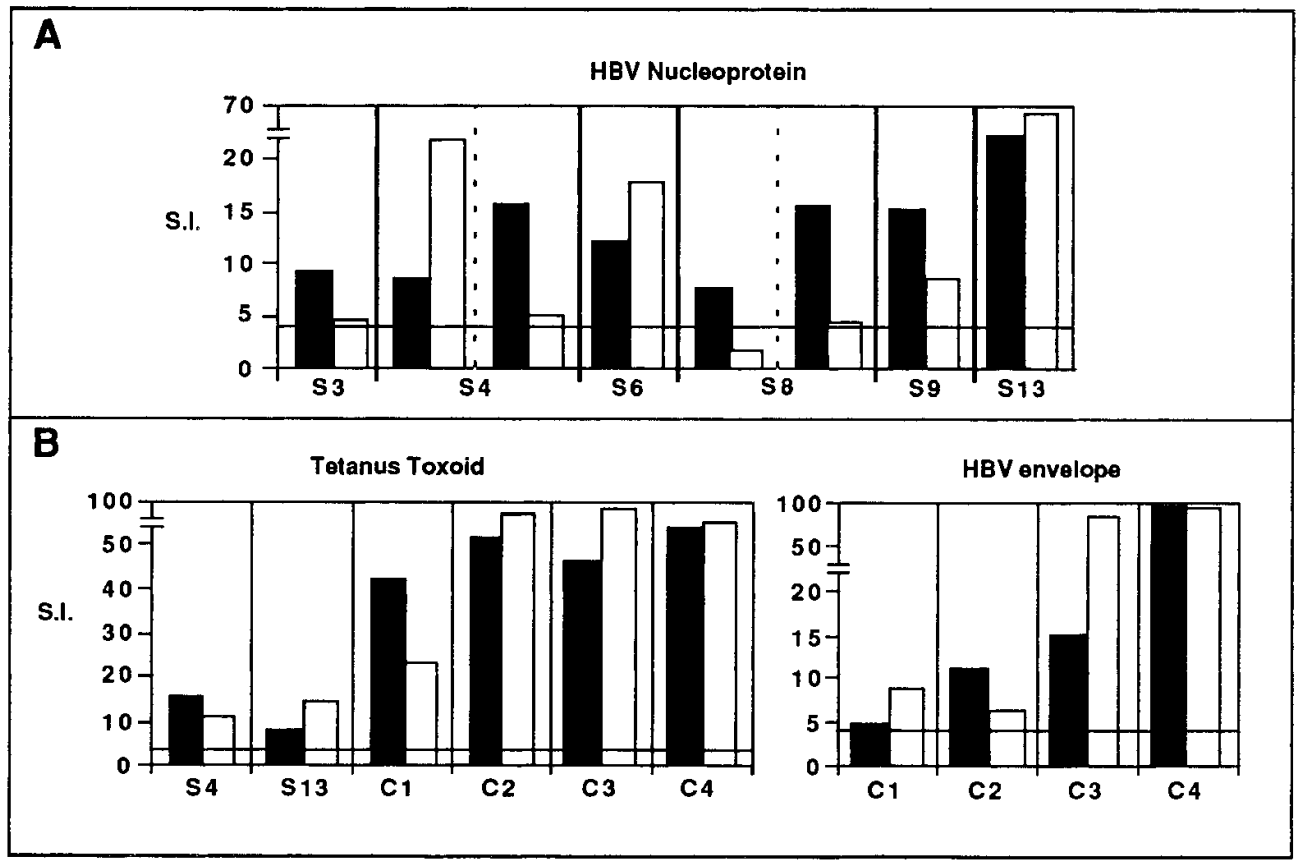

Figure 6. Effect of depletion of activated $\mathrm{T}$ cells on memory $\mathrm{T}$ cell responses. Proliferative responses of unfractionated T lymphocytes $(\boldsymbol{\square})$ and T lymphocyte populations depleted of cells expressing surface activation markers (HLA-DR, CD69 and CD25) ( $\square$ ) to HBV nucleocapsid antigens $(A)$ or to tetanus toxoid or HBV surface antigens $(B)$ are illustrated. S, Subject recovered from acute hepatitis B; $C$, control subjects. Subjects' numeration corresponds to that used in Table I. Responses were studied at the times after clinical onset reported in Table I.

tential stimulus for maintenance of $\mathrm{T}$ cell memory, we analyzed in parallel viremia by PCR and T cell responses to HBV antigens during the acute phase of hepatitis $\mathrm{B}$ and several years following resolution of disease. Our study shows that the majority $(82 \%)$ of the patients spontaneously recovered from acute hepatitis B were still able to mount vigorous $\mathrm{T}$ cell proliferation to HBV nucleocapsid antigens several years later. Although proliferative responses were generally sustained by HLA class II-restricted CD4+ T-cells, CD8-mediated, HLA

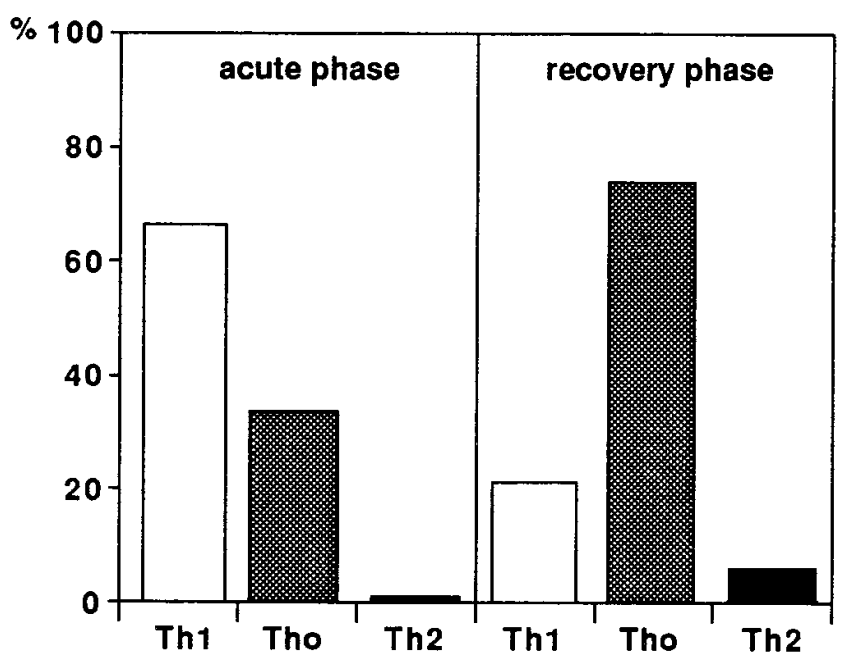

Figure 7. Cytokine profiles in acute hepatitis B and following clinical recovery. Fifteen HBV nucleocapsid-specific $\mathrm{T}$ cell lines produced in the acute phase of infection from nine patients and $19 \mathrm{~T}$ cell lines derived from six subjects recovered from hepatitis (subjects 3, 4, 6, 7, 9, 13 of Table I) were tested for their production of IFN- $\gamma$, IL4, and IL5 upon antigen or peptide stimulation. T cell lines able to produce IFN- $\gamma$, but not IL-4 or IL-5, were defined as Th1; T cell lines able to produce IL-4 and/or IL-5, but not IFN- $\gamma$, were defined as Th2; T cell lines able to produce IFN- $\gamma$ plus IL- 4 and/or IL- 5 were defined as Th0. class I-restricted responses were also observed. The relevance of this finding is supported by the analysis of the anti-viral cytolytic function of CD8+ T cells reported elsewhere (Rehermann, B., C. Ferrari, and F.V. Chisari, manuscript submitted for publication), showing that also HLA class I-restricted responses to the viral envelope, nucleocapsid and polymerase antigens can last for decades following resolution of acute HBV infection. In contrast, significant $\mathrm{T}$ cell responses to HBV envelope antigens were detectable only in a minority of recovered subjects and their levels were always low. This is not

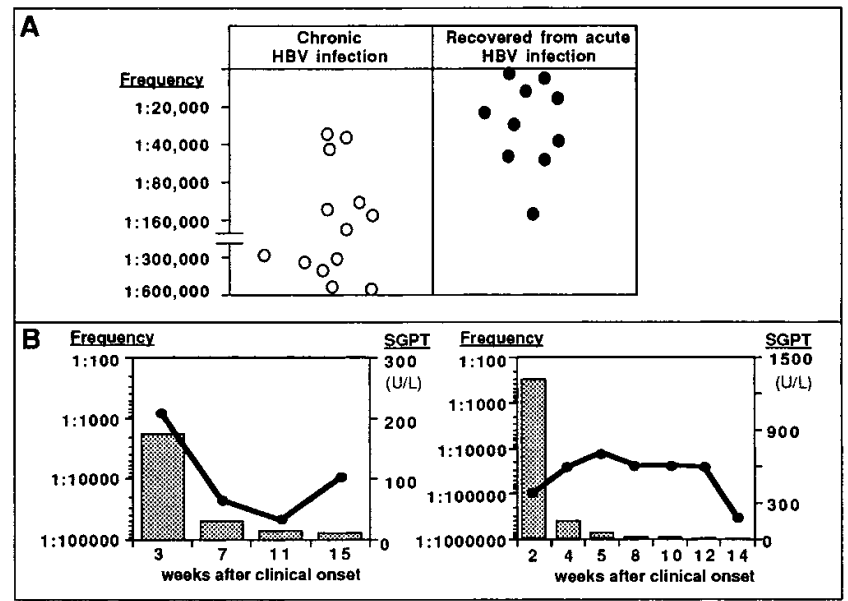

Figure 8. Frequency of circulating HBV nucleocapsid-specific T cells at different stages of $\mathrm{HBV}$ infection. $(A)$ limiting dilution analysis of the $\mathrm{T}$ cell frequency in 13 patients with chronic HBV infection and in 10 of the 14 subjects recovered from acute hepatitis B who were still responsive to HBV nucleocapsid antigens several years after resolution of disease. Dots illustrate the $\mathrm{T}$ cell frequency in individual subjects. $(B)$ behavior of the T cell frequency during the course of acute HBV infection in two representative patients. Bars represent the transaminase levels, dots the $\mathrm{T}$ cell frequency at different time points. 
surprising because these responses are very weak or undetectable even in the acute phase of infection, when high titers of neutralizing anti-envelope antibodies are produced (24).

HBV-DNA was detected in $64 \%$ of the subjects with longlasting $\mathrm{T}$ cell responses but in none of the three non-responder subjects (Table I), suggesting an association between virus persistence and long-term maintenance of $\mathrm{T}$ cell "memory" to HBV nucleoprotein. Viremia, however, was not repeatedly detectable in all determinations, consistent with the presence of very minute amounts of circulating virus, close to the threshold sensitivity of the PCR method, but probably still able to provide periodic stimulation to $\mathrm{HBV}$-specific T cells.

No difference between long-term responders and nonresponders to HBV antigens at the $\mathrm{T}$ cell level was observed with respect to the time elapsed between clinical recovery and analysis of $\mathrm{T}$ cell responses in vitro.

Significant $\mathrm{T}$ cell responses were induced not only by recombinant proteins but also by synthetic peptides. The same antigenic sequences were identified by both direct PBMC stimulation with synthetic peptides and fine specificity analysis of polyclonal $\mathrm{T}$ cell lines induced by whole HBV nucleocapsid antigens. Moreover, the same hierarchy of dominant and subdominant responses detected in the acute phase of infection was maintained after recovery. All these results, together with the lack of significant $\mathrm{T}$ cell responses to recombinant HBV proteins in control subjects, make very unlikely the possibility that our findings are due to a primary $\mathrm{T}$ cell induction in vitro.

This is further supported by the observation that proliferative responses to HBV nucleocapsid antigens were sustained by $\mathrm{T}$ cell subsets expressing the low molecular weight isoform of the CD45 molecule (CD45-RO), a marker for the majority of memory $\mathrm{T}$ cells $(1,29,30)$. CD45-RO is acquired rapidly upon $\mathrm{T}$ cell activation (1) and $\mathrm{CD} 45-\mathrm{RO}+\mathrm{T}$ cells respond more vigorously to recall antigens and provide more effective help to B cells than their naive CD45-RA+ precursors (1). Also the cytokine pattern of CD45-RO+ cells seems to differ from that of CD45-RA+ cells, the former secreting multiple cytokines and thus exhibiting a Th0-like phenotype, the latter producing mainly IL2 $(1,31)$. Interestingly, long-lasting responses to HBV nucleocapsid antigens were dominated by Th0 cells able to produce IFN- $\gamma$, IL4 and IL5, whereas effector T cells derived from the acute stage of infection were mostly Th1. It is still unclear whether the difference in the cytokine profile of responsive $T$ cells in the acute or recovery phase may result from changes of the microenvironment (e.g., cytokines and costimuli) where viral antigens are presented to specific T-cells.

In most of our patients maintenance of $T$ cell responses seems to reflect recent activation in vivo because proliferation could be abrogated by depletion of DR/CD69/IL2-R positive (i.e., activated) T cells. This may suggest that T-cell memory to HBV does not reside in individual cells with a long lifespan but rather in their clonal progeny maintained by periodic restimulation with antigen. Indeed, the effect of activated $\mathrm{T}$ cell depletion may be consistent with the hypothesis of a recent exposure to antigen, but cannot distinguish whether antigen is newly synthesized or stored in the past by follicular dendritic cells $(1,2,32,33)$.

Antigen store by dendritic cells is however expected to gradually run out and memory $\mathrm{T}$ cell responses to eventually wane (1) if the host is not periodically re-exposed to antigen, given the estimated $\mathrm{T}$ cell life span of $\sim 2 \mathrm{yr}$ (34).

While reinfection with $\mathrm{HBV}$ seems to be a quite unlikely mechanism to boost $\mathrm{T}$ cell responses in those patients who do not belong to groups at risk, detection of HBV-DNA in a proportion of our patients suggests that chronic subclinical infections persisting after resolution of acute disease may represent a source of antigen. HBV could survive despite a vigorous anti-viral response either through infection of immunologically privileged sites or through latency (as non-replicating episomal forms of viral DNA) in liver cells or $\operatorname{PBMC}(35,36)$. In alternative, a source of viral antigens may be represented by viral sequences integrated in the host genome (37). Transmission of HBV infection after transplantation of livers and kidneys derived from HBsAg and HBV-DNA negative but anti-HBV antibody positive donors (38-40) supports these possibilities.

In this scenario, viral replication may be suppressed by the immune response until the frequency of antigen-specific $\mathrm{T}$ cells falls below a critical threshold. This may create conditions allowing the virus to reactivate, to synthesize antigen and to eventually boost memory responses, that in turn would neutralize the virus and suppress again its replication. Consistent with this possibility are the variations of virus-specific $\mathrm{T}$ cell frequencies observed in recovered patients, as well as their fluctuations in individual subjects. Also consistent is the observation that $\mathrm{T}$ cell responses were sustained by activated cells in most but not in all experiments. This may reflect the different lapse of time between last encounter with antigen and testing of the $\mathrm{T}$ cell response in vitro. If this interpretation is correct, responses to $\mathrm{HBV}$ antigens measured in recovered subjects should be more properly defined as "ongoing effector" rather than "memory" $T$ cell responses.

An alternative source of stimuli able to reactivate memory $\mathrm{T}$ cell responses may reside in cross-reactive recognition of either self or environmental antigens (41-43) as well as in cytokines secreted after exposure to unrelated antigens (44). These mechanisms may be particularly important for long-lasting responses to tetanus toxoid that are not maintained by persistence of the pathogen but are detectable in vaccine recipients with a frequency and a duration similar to those of the responses to HBV nucleocapsid antigens in hepatitis B recovered subjects.

If the degree of cross-reactive specificity for environmental antigens can influence the strength and duration of T cell memory to a given antigen (42), it is tempting to speculate that also the different vigor of memory responses to HBV nucleocapsid and envelope antigens may be influenced by different levels of cross-reactivity with the environment. The situation in vivo must be however much more complicated, as suggested by the intriguing observation that memory $\mathrm{T}$ cell responses to $\mathrm{HBV}$ envelope antigens are more easily detectable and the frequency of memory $\mathrm{T}$ cells is significantly higher (data not shown) in the peripheral blood of HBsAg vaccine recipients than in the blood of subjects recovered from acute hepatitis B. The molecular and cellular basis of this difference remains undefined.

Though all of the foregoing mechanisms could maintain long-term $\mathrm{T}$ cell memory to HBV nucleocapsid antigens following self-limited hepatitis $\mathrm{B}$, we favor the hypothesis that long-lasting responses are maintained by viral antigen encoded by HBV gene sequences persisting within the host even after complete clinical resolution. The observations that $(i) \mathrm{T}$ cell responses can be sustained by recently activated $\mathrm{T}$ cells circulating at high frequency in the blood of recovered patients, $(b)$ long-lasting $\mathrm{T}$ cell responses are mediated not only by HLA class II but also by HLA class I restricted T cells, (c) half of the recovered subjects are serum HBV-DNA positive by PCR and 
(d) hepatitis can recur upon immunosuppression of anti-HBV antibody positive subjects $(38,39,45-47)$, may be all consistent with our hypothesis that long-lasting $\mathrm{T}$ cell immunity to HBV antigens does not simply reflect long-term $\mathrm{T}$ cell memory but rather active effector $\mathrm{T}$ cell responses continuously restimulated by their interplay with the virus.

\section{Acknowledgments}

We thank Sorin Biomedica S.p.a. (Saluggia, Italy), for providing plasma purified HBV envelope antigens; EuroCetus Italia S.R.L. (Milano, Italy) for the kind gift of rIL2; Luciano Adorini (Roche Milano Ricerche, Milano, Italy) for helpful discussion.

This work was supported in part by the National Institutes of Health (grants AI-26626 and AI-20001), by the Ministry of Universities and Scientific and Technological Research (project on Liver Cirrhosis and Viral Hepatitis), Italy, by a grant from Associazione Italiana per la Ricerca sul Cancro (AIRC) and by the National Research Council (CNR grant 95, 00894 PF41), Italy.

\section{References}

1. Gray, D. 1993. Immunological memory. Annu. Rev. Immunol. 11:49-77.

2. Mackay, R.C. 1993. Immunological memory. Adv. Immunol. 53:217-265.

3. Sprent, J. 1994. T and B cell memory. Cell. 76:315-322.

4. Sprent, J., and D.F. Tough. 1994. Lymphocyte life-span and memory. Science (Wash. DC). 265:1395-1400.

5. Bradley, L.M., M. Croft, and S.L. Swain. 1993. T-cell memory: new perspectives. Immunol. Today. 14:197-199.

6. Zinkernagel, R.M. 1990. Antiviral T-cell memory? Curr. Top. Microbiol. Immunol. 159:65-78.

7. Vitetta, E.S., M.T. Berton, C. Burger, M. Krepon, W.T. Lee, and X.-M. Yin. 1991. Memory B and T cells. Annu. Rev. Immunol. 9:193-217.

8. Lau, L.L., B.D. Jamieson, T. Somasundaram, and R. Ahmed. 1994. Cytotoxic T-cell memory without antigen. Nature (Lond.). 369:648-652.

9. Hou, S., L. Hyland, K.W. Ryan, A. Portner, and P.C. Doherty. 1994. Virus-specific CD8+ T-cell memory determined by clonal burst. Nature (Lond.). 369:652-654

10. Mullbacher, A. 1994. The long-term maintenance of cytotoxic T cell memory does not require persistence of antigen. J. Exp. Med. 179:317-321.

11. Oehen, S., H. Waldner, T.M. Kundig, H. Hengartner, and R.M. Zinkernagel. 1992. Antivirally protective cytotoxic T cell memory to Lymphocytic Choriomeningitis virus is governed by persisting antigen. J. Exp. Med. 176:1273-1281.

12. Gray, D., and P. Matzinger. 1991. T cell memory is short-lived in the absence of antigen. J. Exp. Med. 174:969-974.

13. Michalak, T.I., C. Pasquinelli, S. Guilhot, and F.V. Chisari. 1994. Hepatitis B virus persistence after recovery from acute viral hepatitis. J. Clin. Invest. 93:230-239.

14. Rehermann, B., J. Person, A. Redeker, P. Fowler, M. Brown, A. Sette, B. Moss, and F.V. Chisari. 1995. The cytotoxic T lymphocyte response to multiple hepatitis B virus polymerase epitopes during and after acute viral hepatitis. J. Exp. Med. 181:1047-1058.

15. Chisari, F.V., and C. Ferrari. 1995. Hepatitis B virus immunopathogenesis. Annu. Rev. Immunol. 13:29-60.

16. Pasek, M., T. Goto, W. Gilbert, B. Zink, H. Schaller, P. Mackay, G. Leadbetter, and K. Murray. 1979. Hepatitis B virus genes and their expression in E. Coli. Nature (Lond.). 282:575.

17. Milich, D.R., A. McLachlan, S. Stahl, P. Wingfield, G.B. Thornton, J.L. Hughes, and J.E. Jones. 1988. Comparative immunogenicity of hepatitis B virus core and e antigens. J. Immunol. 141:3617-3624.

18. Ferrari, C., A. Penna, T. Giuberti, M.J. Tong, E. Ribera, F. Fiaccadori, and F.V. Chisari. 1987. Intrahepatic, nucleocapsid antigen-specific T cells in chronic active hepatitis B. J. Immunol. 139:2050-2058.

19. Saxon, A., J. Feldhaus, and R.A. Robins. 1976. Single step separation of human T and B cells using AET-treated sheep red cells. J. Immunol. Methods. 12:285.

20. Ferrari, C., A. Bertoletti, A. Penna, A. Cavalli, A. Valli, G. Missale, M. Pilli, P. Fowler, T. Giuberti, F.V. Chisari, and F. Fiaccadori. 1991. Identification of immunodominant $\mathrm{T}$ cell epitopes of the hepatitis B virus nucleocapsid antigen. J. Clin. Invest. 88:214-222.

21. Lefkovits, I., and H. Waldmann. 1979. Analysis of cells in the immune system. Cambridge University Press, Cambridge, UK. pp. 1-324.

22. Taswell, C. 1979. Limiting dilution assays for the determination of immunocompetent cell frequencies. I. Data analysis. J. Immunol. 126:1614.

23. Del Prete, G.F., M. De Carli, C. Mastromauro, R. Biagiotti, D. Macchia,
P. Falagiani, M. Ricci, and S. Romagnani. 1991. Purified protein derivative of mycobacterium tubercolosis and excretory-secretory antigen(s) of Toxocara Canis expand in vitro human $\mathrm{T}$ cells with stable and opposite (type $1 \mathrm{~T}$ helper or type $2 \mathrm{~T}$ helper) profile of cytokine production. J. Clin. Invest. 88:346-350.

24. Ferrari, C., A. Penna, A. Bertoletti, A. Valli, A.D. Antoni, T. Giuberti, A. Cavalli, M.-A. Petit, and F. Fiaccadori. 1990. Cellular immune response to hepatitis B virus-encoded antigens in acute and chronic hepatitis B virus infection. J. Immunol. 145:3442-3449.

25. Penna, A., F.V. Chisari, A. Bertoletti, G. Missale, P. Fowler, T. Giuberti, F. Fiaccadori, and C. Ferrari. 1991. Cytotoxic T lymphocytes recognize an HLA-A2-restricted epitope within the hepatitis B virus nucleocapsid antigen. J. Exp. Med. 174:1565-1570.

26. Nayersina, R., P. Folwer, S. Guilhot, G. Missale, A. Cerny, H.-J. Schlicht, A. Vitiello, R. Chesnut, J.L. Person, A.G. Redeker, and F.V. Chisari. 1993 HLA A2 restricted cytotoxic T lymphocyte responses to multiple hepatitis B surface antigen epitopes during hepatitis B virus infection. J. Immunol. 150: 4659-4671.

27. Jung, M. C., U. Spengler, W. Schraut, R. Hoffman, R. Zachoval, J. Eisenburg, D. Eichenlaub, G. Riethmuller, G. Paumgartner, H.W.L. ZieglerHeitbrock, H. Will, and G.R. Pape. 1991. Hepatitis B virus antigen-specific T-cell activation in patients with acute and chronic hepatitis B. J.Hepatol. 13:310-317.

28. Akbar, A.N., M. Salmon, J. Savill, and G. Janossy. 1993. A posible role for bcl-2 in regulating T-cell memory: a "balancing act" between cell death and survival. Immunol. Today. 14:526-532.

29. Merkenschlager, M., L. Terry, R. Edwards, and P.C.L. Beverley. 1988. Limiting dilution analysis of proliferative response in human lymphocyte population defined by the antibody UHCL-1: implications for differential CD45 expression in T cell memory formation. Eur. J. Immunol. 18:1653-1661.

30. Akbar, A.N., L. Terry, A. Timms, P.C.L. Beverley, and G. Janossy. 1988. Loss of CD45R and gain of UCHL-1 reactivity is a feature of primed T cells. J. Immunol. 140:2171-2178.

31. Akbar, A.N., M. Salmon, and G. Janossy. 1991. The synergy between naive and memory $\mathrm{T}$ cells during activation. Immunol. Today. 12:184-188.

32. Schriever, F., and L. Marshall Nadler. 1992. The central role of follicula dendritic cells in lymphoid tissues. Adv. Immunol. 51:243-284.

33. Tew, J.G., M.H. Kosco, G.F. Burton, and A.K. Szakal. 1990. Follicular dendritic cells as accessory cells. Immunol. Rev. 117:185-211.

34. Michie, C.A., A. McLean, C. Alcock, and P.C.L. Beverley. 1992. Lifespan of human lymphocyte subsets defined by CD45 isoforms. Nature (Lond.). 360:264-265.

35. Liang, T.J., H.E. Blum, and J.R. Wands. 1990. Characterization and biological properties of a hepatitis B virus isolated from a patient without hepatitis B virus serologic markers. Hepatology. 12:204-212.

36. Korba, B.E., F.V. Wells, B. Baldwin, P.J. Cote, B.C. Tennant, H. Popper, and J.L. Gerin. 1988. Hepatocellular carcinoma in woodchuck hepatitis virus-infected woodchucks: presence of viral DNA in tumor tissue from chronic carriers and animals serologically recovered from acute infections. Hepatology. 9:461-470.

37. Ganem, D., and H.E. Varmus. 1987. The molecular biology of the hepatitis B virus. Ann. Rev. Biochem. 56:651-693.

38. Chazouillères, O., D. Mamish, M. Kim, K. Carey, L. Ferrel, J.P. Roberts, N.L. Ascher, and T.L. Wright. 1994. "Occult" hepatitis B virus as source of infection in liver transplant recipients. Lancet. 343:142-146.

39. Lowell, J.A., T.K. Howard, H.M. White, S. Shenoy, P.C. Huettner, D.C Brennan, and M.G. Peters. 1995. Serological evidence of past hepatitis B infection in liver donor and hepatitis infection in liver allograf. Lancet. 345:10841085 .

40. Wachs, M.E., W.J. Amend, N.L. Ascher, P.N. Bretan, J. Emond, J.R Lake, J.S. Melzer, J.P. Roberts, S.J. Tomlanovich, F. Vincenti, and P. Stock. 1995. The risk of transmission of hepatitis from $\mathrm{HBsAg}(-), \mathrm{HBcAb}(+)$, HBIgM(-) organ donors. Transplantation. 59:230-234.

41. Selin, L.K., S.R. Nahill, and R.W. Welsh. 1994. Cross-reactivities in memory cytotoxic $\mathrm{T}$ lymphocyte recognition of heterologous viruses. $J$. Exp. Med. 179:1933-1943.

42. Matzinger, P. 1994. Memories are made of this? Nature (Lond.). 369: 605-606.

43. Beverley, P.C.L. 1990. Is T-cell memory maintained by crossreactive stimulation? Immunol. Today. 11:203-205.

44. Unutmaz, D., P. Pileri, and S. Abrignani. 1994. Antigen independent activation of naive and memory resting T cells by a cytokine combination. J. Exp. Med. 180:1159-1164.

45. Marcellin, P., E. Giostra, M. Martinot-Peignoux, M.-A. Loriot, M.-L. Jaegle, P. Wolf, C. Degott, F. Degos, and J.-P. Benhamou. 1991. Redevelopment of hepatitis B surface antigen after renal transplantation. Gastroenterology. 100:1432-1434.

46. Degos, F., C. Lugassy, C. Degott, A. Debure, F. Carnot, V. Thiers, P. Tiollais, H. Kreis, and C. Brechot. 1988. Hepatitis B virus and hepatitis B-related viral infection in renal transplant recipients. A prospective study of 90 patients. Gastroenterology. 94:151-156.

47. Grumayer, F.R., S. Panzer, P. Ferenci, and H. Gadner. 1989. Recurrence of hepatitis $\mathrm{B}$ in children with serologic evidence of past hepatitis B virus infection undergoing antileukemic chemotherapy. J. Hepatol. 8:232-235. 